Jurnal Keperawatan Silampari

Volume 3, Nomor 1, Desember 2019

e-ISSN :2581-1975

p-ISSN :2597-7482

DOI: https://doi.org/10.31539/jks.v3i1.765

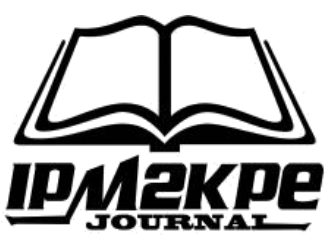

\title{
HUBUNGAN PROGRAM PENGOBATAN KANKER TERHADAP KONSEP DIRI WANITA DENGAN CARSINOMA MAMMAE
}

\author{
Yuli Permata Sari \\ Program Studi Keperawatan, Universitas Muhammadiyah Sumatera Barat \\ yuli_ps86@yahoo.com
}

\begin{abstract}
ABSTRAK
Tujuan penelitian ini adalah untuk mengetahui hubungan program pengobatan kanker terhadap konsep diri pada wanita dengan carsinoma mammae di Poli Klinik Bedah RSUD Dr. Achmad Mochtar Bukittinggi. Desain penelitian ini menggunakan metode deskriptif analitik. Hasil penelitian ini didapatkan lebih dari separuh responden yang melakukan program pengobatan kanker di poli klinik bedah RSUD Dr. Achmad Mochtar Bukittinggi adalah 19 orang $(63,3 \%)$ dan lebih dari separuh didapatskan konsep diri negatif pada wanita dengan carsinoma mammae sebanyak 16 responden (53,3\%) di poli klinik bedah RSUD Dr Achmad Mochtar Bukittinggi. Hasil uji statistik didapatkan nilai $\mathrm{p}=0,046$ maka dapat disimpulkan bahwa terdapat hubungan antara program pengobatan kanker terhadap konsep diri pada wanita dengan carsinoma mammae di poliklinik bedah RSUD Dr. Achmad Mochtar Bukittinggi.
\end{abstract}

Keywords: Cancer Mammae, Konsep Diri, Program Pengobatan Kanker

\begin{abstract}
The purpose of this study was to study the relationship of treatment programs to selfconcept in women with mammary carcinoma in the Polyclinic Surgery Clinic of RSUD Dr. Achmad Mochtar Bukittinggi. The design of this study uses descriptive analytic methods. The results of this study were obtained by more than half of respondents who undertook treatment programs at the poly surgical clinic of RSUD Dr. Achmad Mochtar Bukittinggi is 19 people (63.3\%) and more than half obtained a low self-concept in women with carsinoma mammaes as many as 16 respondents $(53,3 \%)$ in the poly surgical clinic of Dr. Achmad Mochtar Bukittinggi Hospital. The statistical test results obtained $p$ value $=0.046$, it can be concluded that there is a relationship between the treatment program for women with mammary mobilinoma in the surgical clinic of RSUD Dr. Achmad Mochtar Bukittinggi.
\end{abstract}

Keywords: Mammae Cancer, Self Concept, Cancer Treatment Program 


\section{PENDAHULUAN}

Menurut Baradero (2007) kanker merupakan suatu kondisi dimana sel telah kehilangan pengendalian dari mekanisme normalnya, sehingga mengalami pertumbahan yang tidak normal, cepat dan tidak terkendali serta mengancam nyawa hidup penderitanya. Data WHO tahun 2013, insiden kanker dari 12,7 juta kasus tahun 2008 menjadi 14,1 juta kasus di tahun 2012. Sedangkan jumlah kematian meningkat dari 7,6 juta orang tahun 2008 menjadi 8,2 juta tahun 2012. Kanker menjadi penyebab kematian nomor 2 didunia sebesar 13\% setelah penyakit kardiovaskuler. Insiden kenker di tahun 2030 diperkirakan dapat mencapai 26 juta orang dan 17 juta diantaranya meninggal akibat kanker, terlebih untuk negara miskin dan berkembang kejadian akan lebihcepat.Pada tahun 2010 WHO (World Health Organization) memperkirakan angka kejadian yang terkena kanker payudara terdapat 11 juta dan tahun 2030 akan bertambah menjadi 27 juta kematian akibat kanker (Yohannes, 2008). Setiap tahun lebih dari 250.000 kasus baru kanker payudara terdiagnosa di Eropa dan kurang lebih 175.000 di Amerika Serikat.

Kanker payudara merupakan salah satu penyebab utama kematian yang diakibatkan oleh kanker pada perempuan di seluruh dunia. Kanker payudara adalah keganasan yang berasal dari sel kelenjar, saluran kelenjar dan jaringan penunjang payudara, tidak termasuk kulit payudara (Depkes RI, 2009). Menurut Dalimartha (2004) kanker payudara merupakan salah satu penyakit yang paling banyak ditakuti oleh wanita karena kanker payudara banyak menyerang wanita. Berdasarkan hasil penelitian kualitatif yang dilakukan oleh Chris (2005) terhadap penderita kanker payudara pasca tindakan operatif, menunjukkan bahwa subjek penderita kanker payudara pasca tindakan operatif memiliki gambaran konsep diri yang negatif. Penderita kanker payudara menilai secara negatif penampilan fisiknya dan merasa tidak puas dengan kondisi fisiknya tersebut. Penderita kanker payudara merasa tidak memiliki kemampuan baik dalam melakukan aktivitas maupun dalam menjalin hubungan sosialisasi dengan orang lain. Kondisi fisik yang sudah tidak utuh lagi menyebabkan penderita kanker merasa memiliki kelemahan yang berdampak pada perasaan tidak memiliki kemampuan dalam melakukan sesuatu hal. Dengan latar belakang sebagai penderita kanker payudara menyebabkan subjek kehilangan rasa percaya diri, tidak mandiri dan bergantung pada bantuan dari orang lain, serta bersikap tidak jujur terhadap orang lain sehubungan dengan kondisi fisiknya.

Berdasarkan survei awal di RSUD Dr. Ahmad Mochtar Bukittinggi pada tahun 2014 didapatkan angka penderita kanker payudara sebanyak 156 orang dan pada tahun 2015 didapatkan angka penderita kanker payudara 174 orang. Berdasarkan data dari tahun 2014-2015 didapatkan peningkatan angka terjadinya kasus kanker payudara di RSUD Dr. Ahmad Mochtar Bukittinggi. Data yang didapatkan pada bulan Januari, Februari dan Maret angka penderita kanker payudara sebanyak 106 orang dengan ratarata perbulan sebanyak 35 orang. Berdasarkan hasil wawancara pada pasien, peneliti mendapatkan data bahwa pasien yang menderita kanker payudara mengalami gangguan konsep diri (gambaran diri, ideal diri, harga diri, peran diri, dan identitas diri). Klien mengatakan bahwa konsep diri yang paling terganggu yaitu gambaran diri dan peran diri karena kanker payudara sangat mengganggu psikologis klien dan membuatnya merasa tidak sempurna lagi menjadi seorang wanita, dari data didapatkan yang menderita kanker payudara adalah usia produktif (Medical Record RSUD Dr.Achmad Mochtar Bukittinggi, 2016). 


\section{METODE PENELITIAN}

Penelitian ini menggunakan metode deskriptif analitik, yaitu pengumpulan data sekaligus pada suatu saat. Penelitian ini telah dilakukan dan diketahui terdapat hubungan program pengobatan kanker terhadap konsep diri wanita dengan carsinoma mammae di Poliklinik Bedah RSUD Dr. Ahmad Mochtar Bukittinggi tahun 2016. Penelitian ini menggunakan pendekatan coss sectional, pada pendekatan ini pengumpulan data variabel independen dan dependen dilakukan sekaligus pada waktu yang bersamaan.

Populasi dalam penelitian ini adalah semua wanita dengan carsinoma mammae di Poliklinik Bedah RSUD Dr. Ahmad Mochtar Bukittinggi. Berdasarkan data dari Poliklinik Bedah pada bulan januari, februari, maret didapat angka wanita dengan carsinoma mammae berjumlah 106 orang. Sampel dalam penelitian ini berjumlah 30 orang dengan teknik sampling Konsekutif sampling.

Penelitian dilakukan di Poliklinik Bedah RSUD Dr. Ahmad Mochtar Bukittinggi. Peneliti melakukan penelitian di Rumah Sakit ini dikarenakan RSUD Dr. Ahmad Mochtar adalah Rumah Sakit rujukan dan tempat nya strategis dan tidak jauh dari tempat tinggal peneliti, sehingga memudahkan peneliti untuk memperoleh data dan informasi yang dibutuhkan untuk jalannya penelitian ini sehingga lebih efektif dan efesien dalam biaya dan waktu.

\section{HASIL PENELITIAN}

\section{Analisi univariat}

Program Pengobatan Kanker

Tabel. 1

Distribusi Frekuensi Responden Berdasarkan

Program Pengobatan Kanker

\begin{tabular}{lcc}
\hline Program Pengobatan Kanker & F & $\%$ \\
\hline Kombinasi & 20 & 66,7 \\
Pembedahan & 10 & 33,3 \\
\hline Total & 30 & 100 \\
\hline
\end{tabular}

Dari tabel 1 menunjukan bahwa mayoritas responden melakukan program pengobatan kanker kombinasi di Poliklinik Bedah RSUD Dr. Achmad Mochtar Bukittinggi sebanyak 20 (66,7 \%).

\section{Konsep Diri}

Tabel. 2

Distribusi Frekuensi Responden Berdasarkan Konsep Diri

\begin{tabular}{lcc}
\hline \multicolumn{1}{c}{ Konsep Diri } & F & $\%$ \\
\hline Positif & 14 & 46,7 \\
Negatif & 16 & 53,3 \\
\hline Total & 30 & 100 \\
\hline
\end{tabular}


Dari tabel 2 diatas menunjukan sebagian besar responden memiliki konsep diri negatif sebanyak 16 orang $(53,3)$ di Poliklinik Bedah RSUD Dr. Achmad Mochtar Bukittinggi tahun 2016.

\section{Analisis Bivariat}

Tabel. 3

Hubungan Program Pengobatan Kanker terhadap Konsep Diri Wanita dengan Carsinoma Mammae

\begin{tabular}{|c|c|c|c|c|c|c|c|c|}
\hline \multirow{3}{*}{$\begin{array}{c}\text { Program } \\
\text { Pengobatan Kanker }\end{array}$} & \multicolumn{4}{|c|}{ Konsep Diri } & \multirow{2}{*}{\multicolumn{2}{|c|}{ Total }} & \multirow{3}{*}{ p value } & \multirow{3}{*}{ OR } \\
\hline & \multicolumn{2}{|c|}{ Negatif } & \multicolumn{2}{|c|}{ Positif } & & & & \\
\hline & $f$ & $\%$ & $f$ & $\%$ & $f$ & $\%$ & & \\
\hline Kombinasi & 7 & 36,8 & 12 & 63,2 & 19 & 100 & \multirow{3}{*}{0,046} & \multirow{3}{*}{0,130} \\
\hline Pembedahan & 9 & 81,8 & 2 & 18,2 & 11 & 100 & & \\
\hline Total & 16 & 53,3 & 14 & 46,7 & 30 & 100 & & \\
\hline
\end{tabular}

Dari tabel 3 diatas menunjukkan bahwa klien yang mengalami pengobatan kombinasi memiliki konsep diri yang negatif sebanyak 7 orang $(36,8 \%)$, klien yang mengalami pengobatan kombinasi memiliki konsep diri positif sebanyak 12 orang $(63,2 \%)$. Klien yang memiliki program pengobatan kanker pembedahan memiliki konsep diri negatif sebanyak 9 orang $(81,8 \%)$, klien yang memiliki pengobatan kanker pembedahan memiliki konsep diri positif 2 orang (18,2\%). Hasil uji statistik di dapatkan $\mathrm{p}$ value 0,046 dapat disimpulkan bahwa adanya hubungan antara program pengobatan kanker dengan konsep diri wanita dengan. Hasil analisis di dapatkan bahwa nilai OR = 0,130 berarti pasien yang mengalami kombinasi beresiko 0,130 kali dengan konsep diri yang negatif dibandingkan dengan konsep diri positif.

\section{PEMBAHASAN}

\section{Analisis Univariat}

\section{Program Pengobatan Kanker}

Hasil penelitian didapatkan bahwa lebih dari separoh responden melakukan program pengobatan kanker kombinasi yaitu 19 orang dengan persentase 63,3\% di Poliklinik Bedah RSUD Dr. Achmad Mochtar Bukittinggi tahun 2016. Pengobatan kanker payudara didasarkan atas tahap penyakit dan beberapa faktor lain. Wanita saat ini mempunyai lebih banyak pilihan dalam pengobatan kanker payudara daripada sebelumnya. Pengobatan kanker payudara biasanya meliputi kombinasi pembedahan, kemoterapi, dan terapi radiasi. Pengobatan kanker secara menyeluruh melalui tindakan pembedahan masih merupakan modalitas pengobatan yang terbaik dan paling sering digunakan. Biopsi biasanya jenis pembedahan pertama bagi seseorang wanita dengan kanker payudara yang akan dilakukan. Tujuan dari melakukan biopsi ini adalah untuk menentukan bila ada massa malignansi dan jenis kanker payudara tersebut. Sering kali wanita tersebut diberi pilihan tentang tindakan biopsi yang dilakukan sebagai prosedur satu tahap atau prosedur dua tahap.

Prosedur satu tahap dilakukan dengan anastesi umum dengan potongan beku cepat. Bila potongan beku ini memperlihatkan malignansi, ahli bedah melakukan mastektomi jika tepat. Prosedur satu tahap ini memungkinkan biopsi dan pembedahan 
dilakukan dengan anastesi umum yang memerlukan waktu untuk penyembuhan. Dalam prosedur dua tahap, biopsi biasanya dilakukan dengan anastesi lokal, dan wanita tersebut dipulangkan kerumah. Karena hasil biopsi sudah ada dokter memberitahukan pasien dan keluarga tentang pengobatan yang dianjurkan. Pendekatan ini memungkinkan pasien dan keluarganya mempunyai waktu untuk mempertimbangkan pilihan dan menerima diagnosa dan kemungkinan kehilangan payudara sebelum pembedahan mayor dilakukan. Selain itu, pendekatan ini memungkinkan wanita untuk mengungkapkan pilihan kedua jika diinginkan.

Terapi radiasi dapat digunakan untuk mengontrol penyakit malignansi bila tumor tidak dapat diangkat secara pembedahan atau ada metastase pada nodus lokal. Terapi rasiasi dapat digunakan sebagai pengobatan primer untuk kanker payudara tahap 1 dan tahap 2. Laju bertahan hidup dapat dibandingkan dengan penanganan. Ini tidaklah mengherankan karena kedua nya dipertimbangkan sebagai bentuk pengobatan lokal. Sebagai terapi lokal tindakan ini tidak berdampak pada adanya mikrometastase yang jauh terapi tidak secara klinis dapat terdeteksi pada waktu diagnosis. Keuntungan radiasi primer kemungkinan baik kontrol tumor lokal maupun pemeliharaan payudara. Terapi radiasi dapat juga digunakan untuk mengatasi kanker payudara terinflamasi sebelum diberikan radiasi. Selain itu terapi radiasi mungkin juga digunakan untuk mengatasi penyakit yang kambuh secara lokal, untuk menangani fungsi ovarium, dan untuk pengatasi gejala dari metastase penyakit. Efek samping segera tampak pada radiasi ini adalah reaksi kulit. Fraktur tulang kostal dan pneumonitis adalah efek lanjut. Limfedema mungkin juga tampak jika aksila terpajang penyinaran radiasi tersebut.

Kemoterapi adalah penggunaan preparat antineoplastik sebagai upaya untuk membunuh sel-sel tumor dengan mengganggu fungsi dan reproduksi selular. Kemoterapi terutama digunakan untuk mengobati penyakit sistemik daripada lesi setempat dan dapat diatasi dengan pembedahan atau radiasi. Kemoterapi mungkin dikombinasi dengan pembedahan atau terapi radiasi, atau kedua-duanya, untuk menurunkan ukuran tumor sebelum operasi, untuk merusak semua sel-sel tumor yang tertinggal pasca operasi, atau untuk mengobati beberapa bentuk leukimia. Kemoterapi yang menggunakan agen antineuplasma dan obat hormonal memegang peranan penting dalam pengobatan kanker paru. Peran dari agen ini cepat berubah sama cepatnya dengan peningkatan pemahaman tentang kanker payudara dan biologi tumor. Kepentingan dari utama peran agen-agen antineuplastik pada kanker payudara primer adalah pemahaman bahwa banyak pasien waktu didiagnosis telah mengalami penyakit mikrometastasis yang tidak dapat dideteksi secara klinis oleh metode yang ada. Menurut asumsi peneliti didapatkan bahwa program pengobatan kanker terdiri pada pembedahan, kombinasi. pasien setelah dilakukan pembedahan akan mengalami perubahan pada konsep dirinya merasa kehilangan, malu dengan dirinya sekarang karena payudara dibuang.

\section{Konsep Diri}

Hasil penelitian didapatkan bahwa mayoritas konsep dirinya negatif sebanyak 16 orang responden dengan persentase (53,3\%). Di Poliklinik Bedah RSUD Dr. Achmad Mochtar Bukittinggi tahun 2016. Konsep diri didefinisikan secara berbeda oleh para ahli. Seifert dan Hoffnung (dalam desmita, 2009) mendefinisikan konsep diri sebagai suatu pemahaman mengenai diri atau ide tentang diri sendiri. Erikson (dalam Sawitri, 2005) mengemukakan tentang konsep diri merupakan pengenalan diri bahwa setiap orang memiliki beberapa fase yang sejalan dengan berbagai relasidan situasi yang mereka temukan dalam masa hidup. Konsep diri memusatkan perhatian pada apa yang 
mereka sebut core self yang merupakan cara orang untuk menunjukan stabilitas dan kontinuitas dari kepribadian individu yang sama dari waktu ke waktu. Konsep diri mencakup seluruh pandangan individu akan dimensi fisiknya, karakteristik pribadinya, motivasinya, kelemahannya, kelebihannya atau kecakapannya, kegagalannya, dan sebagainya (Desmita, 2005).

Calhoun dan Acocella (dalam Rose, 2009) mengatakan cara pandang individu dengan yang lainya akan membentuk suatu konsep tentang dirinya, konsep tentang diri merupakan hal yang terpenting bagi kehidupan individu karena konsep diri menentukan bagaimana individu bertindak dalam berbagai situasi. Konsep diri merupakan penentu sikap individu dalam bertingkah laku, artinya apabila individu cenderung berpikir akan berhasil, maka hal ini merupakan kekuatan atau dorongan yang akan membuat individu menuju kesuksesan. Sebaliknya jika individu berpikir akan gagal, maka hal ini sama saja mempersiapkan kegagalan bagi dirinya. Orang yang percaya diri biasanya mempunyai inisitiaf, kreatif dan optimis terhadap masa depan, mampu menyadari kelemahan dan kelebihan diri sendiri, berpikir positif, menganggap semua permasalahan pasti ada jalan keluarnya. Orang yang tidak percaya diri ditandai dengan sikap-sikap yang cenderung melemahkan semangat hidupnya, seperti minder, pesimis, pasif, dan cenderung apatis (Desmita, 2009).

Berk (dalam Dariyo, 2007) konsep diri (self-concept) ialah gambaran diri sendiri yang bersifat menyeluruh terhadap keberadaan diri seseorang. Konsep diri ini bersifat multi-aspek yaitu meliputi 4 (empat) aspek seperti (1) aspek fisiologis, (2) psikologis, (3) psikososiologis, (4) psiko-etika dan moral. Gambaran konsep diri berasal dari interaksi antara diri sendiri maupun antara diri dengan orang lain (lingkungan sosiainya). Oleh karna itu, konsep diri sebagai cara pandang seseorang mengenai diri sendiri untuk memahami keberadaan diri sendiri maupun memahami orang lain. Blasi \& Glodis (dalam Vasta,et.al,2004) para ahli psikologi perkembangan menyebut pemahaman terhadap keberadaan diri sendiri sebagai self-existentian. Pemahaman keberadaan diri sendiri berhubungan erat dengan pemahaman terhadap karakteristik pribadi secara objektif terhadap diri sendiri, atau yang disebut sebagai kategori diri (self-categorial).

Calhoun dan Acocella dalam (Isabella, 2011) berpendapat bahwa individu dengan konsep diri positif akan mampu merancang tujuan-tujuan hidup yang sesuai dengan realita, sehingga lebih besar kemungkinan individu untuk mencapai tujuan hidupnya. Calhoun dan Acocella juga mengemukakan bahwa seseorang yang memiliki konsep diri positif memungkinkan orang tersebut untuk dapat maju ke depan secara bebas, berani dan spontan, serta mampu menghargai orang lain.

Konsep diri negative pada orang yang memiliki konsep diri negatif meliputi tidak tahan terhadap kritikan, mudah marah, merasa tidak disukai orang, merasa rendah diri, merasa tidak diperhatikan oleh lingkungan sekitar, bersikap pesimis terhadap kompetisi dilingkungan sekitar, menarik diri dari lingkungan, hilangnya rasa percaya diri, hilangnya kemandirian. Menurut asumsi peneliti bahwa konsep diri negatif tidak tahan terhadap kritikan, mudah marah, merasa tidak disukai orang, merasa rendah diri, merasa tidak diperhatikan oleh lingkungan sekitar. Berbanding terbalik dengan konsep diri seseorang yang positif merupakan seseorang yang yakin akan kemampuannya dalam mengatasi suatu masalah, merasa sama dengan orang lain, dapat menerima keadaan yang dialaminya, menyadari bahwa setiap orang mempunyai berbagai perasaan, dan mampu memperbaiki dirinya karena ia sanggup mengungkapkan aspek-aspek kepribadian yang tidak disenanginya dan berusaha merubahnya. 


\section{Analisis Bivariat \\ Hubungan Program Pengobatan Kanker Terhadap Konsep Diri Wanita dengan Carsinoma Mammae}

Hasil penelitian didapatkan bahwa klien yang mengalami pengobatan kombinasi memiliki konsep diri yang negatif sebanyak 7 orang $(36,8 \%)$, klien yang mengalami pengobatan kombinasi memiliki konsep diri positif sebanyak 12 orang $(63,2 \%)$. Klien yang memiliki program pengobatan kanker pembedahan memiliki konsep diri negatif sebanyak 9 orang $(81,8 \%)$, klien yang memiliki pengobatan kanker pembedahan memiliki konsep diri positif 2 orang $(18,2 \%)$. Hasil uji statistik di dapatkan p value 0,046 dapat disimpulkan bahwa adanya hubungan antara program pengobatan kanker dengan konsep diri pasien. Hasil analisis di dapatkan bahwa nilai $\mathrm{OR}=0,130$ berarti pasien yang mengalami kombinasi beresiko 0,130 kali dengan konsep diri yang negatif dibandingkan dengan konsep diri positif.

Hasil penelitian ini diperkuat penelitian yang dilakukan oleh Oetami, dkk (2014) menunjukan bahwa penderita kanker payudara memiliki konsep diri yang positif. Hal ini ditandai dengan klien yang menyatakan optimis menjalani pengobatan sebesar $80 \%$, tidak merasa malu dengan kondisi sakitnya sebesar $72 \%$, tidak mengalami stress sebesar $64 \%$ dan tidak mengalami reaksi amarah sebesar $64 \%$.

Pengobatan kanker secara menyeluruh melalui tindakan pembedahan masih merupakan modalitas pengobatan yang terbaik dan paling sering digunakan. Biopsi biasanya jenis pembedahan pertama bagi seseorang wanita dengan kanker payudara yang akan dilakukan. Tujuan dari melakukan biopsi ini adalah untuk menentukan bila ada massa malignansi dan jenis kanker payudara tersebut. Sering kali wanita tersebut diberi pilihan tentang tindakan biopsi yang dilakukan sebagai prosedur satu tahap atau prosedur dua tahap. Prosedur satu tahap dilakukan dengan anastesi umum dengan potongan beku cepat. Bila potongan beku ini memperlihatkan malignansi, ahli bedah melakukan mastektomi jika tepat. Prosedur satu tahap ini memungkinkan biopsi dan pembedahan dilakukan dengan anastesi umum yang memerlukan waktu untuk penyembuhan. Dalam prosedur dua tahap, biopsi biasanya dilakukan dengan anastesi lokal, dan wanita tersebut dipulangkan kerumah. Karena hasil biopsi sudah ada dokter memberitahukan pasien dan keluarga tentang pengobatan yang dianjurkan. Pendekatan ini memungkinkan pasien dan keluarganya mempunyai waktu untuk mempertimbangkan pilihan dan menerima diagnosa dan kemungkinan kehilangan payudara sebelum pembedahan mayor dilakukan. Selain itu, pendekatan ini memungkinkan wanita untuk mengungkapkan pilihan kedua jika diinginkan.

Terapi radiasi dapat digunakan untuk mengontrol penyakit malignansi bila tumor tidak dapat diangkat secara pembedahan atau ada metastase pada nodus lokal. Terapi rasiasi dapat digunakan sebagai pengobatan primer untuk kanker payudara tahap 1 dan tahap 2. Laju bertahan hidup dapat dibandingkan dengan penanganan. Ini tidaklah mengherankan karena kedua nya dipertimbangkan sebagai bentuk pengobatan lokal. Sebagai terapi lokal tindakan ini tidak berdampak pada adanya mikrometastase yang jauh terapi tidak secara klinis dapat terdeteksi pada waktu diagnosis. Keuntungan radiasi primer kemungkinan baik kontrol tumor lokal maupun pemeliharaan payudara. Terapi radiasi dapat juga digunakan untuk mengatasi kanker payudara terinflamasi sebelum diberikan radiasi. Selain itu terapi radiasi mungkin juga digunakan untuk mengatasi penyakit yang kambuh secara lokal, untuk menangani fungsi ovarium, dan untuk pengatasi gejala dari metastase penyakit. Efek samping segera tampak pada radiasi ini 
adalah reaksi kulit. Fraktur tulang kostal dan pneumonitis adalah efek lanjut. Limfedema mungkin juga tampak jika aksila terpajang penyinaran radiasi tersebut.

Kemoterapi adalah penggunaan preparat antineoplastik sebagai upaya untuk membunuh sel-sel tumor dengan mengganggu fungsi dan reproduksi selular. Kemoterapi terutama digunakan untuk mengobati penyakit sistemik daripada lesi setempat dan dapat diatasi dengan pembedahan atau radiasi. Kemoterapi mungkin dikombinasi dengan pembedahan atau terapi radiasi, atau kedua-duanya, untuk menurunkan ukuran tumor sebelum operasi, untuk merusak semua sel-sel tumor yang tertinggal pasca operasi, atau untuk mengobati beberapa bentuk leukimia. Kemoterapi yang menggunakan agen antineuplasma dan obat hormonal memegang peranan penting dalam pengobatan kanker paru. Peran dari agen ini cepat berubah sama cepatnya dengan peningkatan pemahaman tentang kanker payudara dan biologi tumor. Kepentingan dari utama peran agen-agen antineuplastik pada kanker payudara primer adalah pemahaman bahwa banyak pasien waktu didiagnosis telah mengalami penyakit mikrometastasis yang tidak dapat dideteksi secara klinis oleh metode yang ada. Konsep diri didefinisikan secara berbeda oleh para ahli. Seifert dan Hoffnung (dalam desmita, 2009) mendefinisikan konsep diri sebagai suatu pemahaman mengenai diri atau ide tentang diri sendiri.

Erikson (dalam Sawitri, 2005) mengemukakan tentang konsep diri merupakan pengenalan diri bahwa setiap orang memiliki beberapa fase yang sejalan dengan berbagai relasidan situasi yang mereka temukan dalam masa hidup. Konsep diri memusatkan perhatian pada apa yang mereka sebut core self yang merupakan cara orang untuk menunjukan stabilitas dan kontinuitas dari kepribadian individu yang sama dari waktu ke waktu. Konsep diri mencakup seluruh pandangan individu akan dimensi fisiknya, karakteristik pribadinya, motivasinya, kelemahannya, kelebihannya atau kecakapannya, kegagalannya, dan sebagainya (Desmita, 2009). Calhoun dan Acocella (dalam Rose, 2009) mengatakan cara pandang individu dengan yang lainya akan membentuk suatu konsep tentang dirinya, konsep tentang diri merupakan hal yang terpenting bagi kehidupan individu karena konsep diri menentukan bagaimana individu bertindak dalam berbagai situasi. Konsep diri merupakan penentu sikap individu dalam bertingkah laku, artinya apabila individu cenderung berpikir akan berhasil, maka hal ini merupakan kekuatan atau dorongan yang akan membuat individu menuju kesuksesan. Sebaliknya jika individu berpikir akan gagal,maka hal ini sama saja mempersiapkan kegagalan bagi dirinya. Orang yang percaya diri biasanya mempunyai inisitiaf, kreatif dan optimis terhadap masa depan, mampu menyadari kelemahan dan kelebihan diri sendiri, berpikir positif, menganggap semua permasalahan pasti ada jalan keluarnya. Orang yang tidak percaya diri ditandai dengan sikap-sikap yang cenderung melemahkan semangat hidupnya, seperti minder, pesimis, pasif, dan cenderung apatis (Desmita, 2008).

Berk (dalam Dariyo, 2007) Konsep diri (self-concept) ialah gambaran diri sendiri yang bersifat menyeluruh terhadap keberadaan diri seseorang. Konsep diri ini bersifat multi-aspek yaitu meliputi 4 (empat) aspek seperti (1) aspek fisiologis, (2) psikologis, (3) psikososiologis, (4) psiko-etika dan moral. Gambaran konsep diri berasal dari interaksi antara diri sendiri maupun antara diri dengan orang lain (lingkungan sosiainya). Oleh karna itu, konsep diri sebagai cara pandang seseorang mengenai diri sendiri untuk memahami keberadaan diri sendiri maupun memahami orang lain. Blasi \& Glodis (dalam Vasta,et.al, 2004) para ahli psikologi perkembangan menyebut pemahaman terhadap keberadaan diri sendiri sebagai self-existentian. Pemahaman 
keberadaan diri sendiri berhubungan erat dengan pemahaman terhadap karakteristik pribadi secara objektif terhadap diri sendiri, atau yang disebut sebagai kategori diri (self-categorial).

Calhoun dan Acocella (Isabella, 2011) berpendapat bahwa individu dengan konsep diri positif akan mampu merancang tujuan-tujuan hidup yang sesuai dengan realita, sehingga lebih besar kemungkinan individu untuk mencapai tujuan hidupnya. Calhoun dan Acocella juga mengemukakan bahwa seseorang yang memiliki konsep diri positif memungkinkan orang tersebut untuk dapat maju ke depan secara bebas, berani dan spontan, serta mampu menghargai orang lain. Menurut asumsi peneliti bahwa orang yang memiliki konsep diri negatif pada orang yang memiliki konsep diri negatif meliputi tidak tahan terhadap kritikan, mudah marah, merasa tidak disukai orang, merasa rendah diri, merasa tidak diperhatikan oleh lingkungan sekitar, bersikap pesimis terhadap kompetisi dilingkungan sekitar, menarik diri dari lingkungan, hilangnya rasa percaya diri, hilangnya kemandirian. Sedangkan, konsep diri positif meliputi: Ia yakin akan kemapuannya mengatasi masalah, Merasa sama dengan orang lain, Dapat menerima keadaan yang dialaminya, Menyadari bahwa setiap orang mepunyai berbagai perasaan, keinginan dan perilaku yang tidak seluruhnya disetujui masyarakat. Mampu memperbaiki dirinya karena ia sanggup mengungkapkan aspek-aspek kepribadian yang tidak disenanginya dan berusaha merubahnya.

\section{SIMPULAN}

Berdasarkan penelitian yang telah dilakukan tentang hubungan program pengobatan kanker terhadap konsep diri wanita dengan carcinoma mammae di Poliklinik Bedah RSUD Dr. Achmad Mochtar Bukittinggi, dengan jumlah 30 responden didapatkan kesimpulan yaitu sebagaian besar responden melakukan program pengobatan kanker kombinasi di Poliklinik Bedah RSUD Dr. Achmad Mochtar Bukittinggi sebanyak 19 (63,3 \%) dan sebagian besar responden memiliki konsep dirinegatif sebanyak 16 orang $(53,3)$. Terdapat hubungan yang bermakna antara program pengobatan kanker terhadap konsep diri wanita dengan carcinoma mammae ( $\mathrm{p}$ $=0,046)$.

\section{SARAN}

\section{Bagi Peneliti}

Untuk menambah wawasan pengetahuan peneliti tentang hubungan program pengobatan kanker terhadap konsep diri wanita dengan carsinoma mammae dan menambah wawasan peneliti di bidang keperawatan jiwa dan juga menambah pemahaman penelitian di bidang riset keperawatan.

\section{Bagi Institusi Pendidikan}

Hasil penelitian ini hendaknya dapat dijadikan masukkan bagi peserta didik untuk mengetahui hubungan program pengobatan kanker dengan konsep diri, serta sebagai informasi terbaru untuk dijadikan masukan tambahan dalam pendidikan.

\section{Bagi Institusi Rumah Sakit}

Hasil penelitian ini dapat digunakan sebagai masukan bagi institusi RSUD Dr.Ahmad Mochtar untuk mengetahui tentang hubungan program pengobatan kanker terhadap konsep diri wanita dengan carsinoma mammae di Poliklinik Bedah RSUD Dr. Ahmad Mochtar Bukittinggi tahun 2016. 


\section{DAFTAR PUSTAKA}

Baradero, M. (2007). Asuhan Keperawatan pada Klien dengan Kanker. Jakarta: EGC

Chris. (2005). Kesejahteraan Psikologi. Yogyakarta: Maximus

Dalimartha, S. (2004). Deteksi Dini Kanker dan Simplisia Anti Kanker. Jakarta: Penebar Swadaya

Dariyo, A. (2007). Psikologi Perkembangan. Psikologi Perkembangan Anak Tiga Tahun Pertama (Psikologi Atitma). Bandung: PT. Refika Aditama

Depkes. (2009). Pencegahan Kanker Leher Rahim dan Kanker Payudara. Jakarta: Depkes RI

Desmita. (2009). Psikologi Perkembangan Peserta Didik. Bandung: PT. Remaja Rosdakarya

Isabella, Y. J. (2011). Analisis Pengaruh Labelling terhadap Konsep Diri pada Tokoh Shinagawa Daichi dalam Drama Yankee-Kun To Megane-Chan. Skripsi. Universitas Bina Nusantara

Oetami, F. (2014). Analisis Dampak Psikologis Pengobatan Kanker Payudara di RS. Dr. Wahidin Sudirohusodo Makasar

Vasta, R., Miller, S. A., Ellis, S. (2004). Child Psychology. USA: Wiley John Wiley \& Sons,Inc. (Fourth Edition)

Wima A, Andayani, TR. Sawitri, R. (2005). Hubungan Konsep Diri dengan Penyesuaian Sosial Siswa Kelas Akselerasi di SMP Negeri 2 dan SMP PL Domenico Savio Semarang. Jurnal Psikolog 1-19

Yohanes. (2008). Kanker Ancaman Negara Berkembang. Diperoleh dari: http://www.kanker.com

Yulianto, Rose. (2009). Pengaruh Konsep Diri terhadap Motivasi Karyawan PT. Telkom Purwokerto.UMP 